in vivo $35: 467-474(2021)$

doi:10.21873/invivo.12280

\title{
Coexistence of Emphysema With Non-small-cell Lung Cancer Predicts the Therapeutic Efficacy of Immune Checkpoint Inhibitors
}

\author{
YUSUKE TAKAYAMA ${ }^{1}$, TAKASHI NAKAMURA ${ }^{2}$, YUKI FUKUSHIRO ${ }^{1}$, \\ SHOHEI MISHIMA ${ }^{1}$, KEN MASUDA ${ }^{1}$ and HIROYASU SHODA ${ }^{1}$ \\ ${ }^{1}$ Department of Respiratory Medicine, Hiroshima Citizens Hospital, Hiroshima, Japan; \\ ${ }^{2}$ Department of Respiratory Medicine, Hiroshima General Hospital, Hatsukaichi, Japan
}

\begin{abstract}
Background/Aim: Chronic obstructive pulmonary disease coexisting with non-small-cell lung cancer (NSCLC) was reported to be associated with a longer progression-free survival (PFS) in patients treated with immune checkpoint inhibitors (ICIs). In the present study, we investigated the impact of emphysematous change on the treatment response to ICIs in patients with NSCLC. Patients and Methods: A total of 153 patients with advanced NSCLC who received ICIs (nivolumab, pembrolizumab, or atezolizumab) at our hospital from January 2016 to May 2019 were retrospectively enrolled. Results: According to the Goddard scoring system, 71 (46.4\%) patients were classified as having emphysema and 82 (53.6\%) as having no emphysema. Multivariate analysis showed that a good performance status and coexisting emphysema (hazard ratio $=0.49 ; 95 \%$ confidence intervaI $=0.28-0.84 ; p=0.010$ ) were independent predictors of a better PFS. Conclusion: Recognizing emphysema coexisting with NSCLC may help predict the therapeutic efficacy of ICIs in such patients.
\end{abstract}

Lung cancer is a major cause of cancer-related death worldwide (1). Although immune checkpoint inhibitors (ICIs) are an approved treatment for advanced non-small-cell lung cancer (NSCLC), primary resistance to ICIs is common (2-4). Expression of programmed cell death ligand 1 (PDL1) in tumor cells (5), tumor mutation burden (6), and the

This article is freely accessible online.

Correspondence to: Yusuke Takayama, Department of Respiratory Medicine, Hiroshima Citizens Hospital, Hiroshima City, Hiroshima 730-8518, Japan. Tel: +81 822212291, Fax: +81 822235514, e-mail: highmt@city-hosp.naka.hiroshima.jp

Key Words: non-small-cell lung cancer, immune checkpoint inhibitors, emphysema, Goddard scoring system. gene-expression signature of inflammation (7) have emerged as potential predictive biomarkers of the efficacy of inhibitors of the programmed cell death 1 (PD1) axis. However, these biomarkers are insufficient for evaluating a patient's response to ICIs.

Cigarette smoking is the most common risk factor for lung cancer and chronic obstructive pulmonary disease (COPD) (8). COPD is considered an important risk factor for lung cancer (9) and has been shown to worsen the survival of patients with lung cancer (10). Previous studies revealed that current or former smokers with NSCLC are more likely to respond to ICI therapy $(2,3)$. Recently, it was reported that the presence of COPD was associated with longer progression-free survival (PFS) in patients with NSCLC treated with ICIs (11-13).

COPD is a heterogeneous syndrome consisting of emphysema, chronic bronchitis, and small airway disease. Emphysema is characterized by abnormal and permanent enlargement of airspaces distal from terminal bronchioles, which can be visualized by computed tomography (CT). To the best of our knowledge, no previous study has evaluated the prognostic significance of pulmonary emphysema in patients with NSCLC treated with ICIs. In the present study, we investigated the impact of emphysematous change on the treatment response to ICIs in patients with NSCLC.

\section{Patients and Methods}

Patient population. Patients with advanced NSCLC who received ICIs (nivolumab, pembrolizumab, or atezolizumab) at Hiroshima City Hiroshima Citizens Hospital from January 2016 to May 2019 were retrospectively enrolled in this study. The characteristics and clinical data of the patients before administration of single-agent anti-PD1/PD-L1 were obtained. This study was approved by the Ethical Review Board of Hiroshima City Hiroshima Citizens Hospital (approval number No. 2019-62, July 11, 2019). Patient approval or the requirement for informed consent was waived because this study was performed during routine clinical practice. 
Table I. Characteristics of the study patients $(N=153)$.

\begin{tabular}{|c|c|c|c|c|}
\hline \multirow[t]{2}{*}{ Characteristic } & & \multicolumn{2}{|c|}{ Emphysema } & \multirow[t]{2}{*}{$p$-Value } \\
\hline & & With $(\mathrm{N}=71)$ & Without $(\mathrm{N}=82)$ & \\
\hline Age (years) & Mean \pm SD & $68.0( \pm 9.5)$ & $68.0( \pm 10.3)$ & 0.968 \\
\hline \multirow[t]{2}{*}{ Sex } & Male & $63(88.7)$ & $52(63.4)$ & $<0.001$ \\
\hline & Female & $8(11.3)$ & $30(36.6)$ & \\
\hline BMI (kg/m2) & Mean \pm SD & $21.7( \pm 3.5)$ & $22.0( \pm 3.8)$ & 0.583 \\
\hline \multirow[t]{4}{*}{ Smoking status } & Never smoker & $0(0 \%)$ & $30(36.6 \%)$ & $<0.001$ \\
\hline & Former smoker & $32(45.1 \%)$ & $28(34.1 \%)$ & \\
\hline & Current smoker & $39(54.9 \%)$ & $23(28.0 \%)$ & \\
\hline & Pack-years, mean \pm SD & $55.2( \pm 31.0)$ & $29.7( \pm 33.5)$ & $<0.001$ \\
\hline \multirow{2}{*}{ ECOG PS, n (\%) } & $0-1$ & $68(95.8 \%)$ & $70(85.4 \%)$ & 0.053 \\
\hline & $2-3$ & $3(4.2 \%)$ & $12(14.6 \%)$ & \\
\hline \multirow{2}{*}{ Histology } & Squamous & $29(40.8 \%)$ & $17(20.7 \%)$ & 0.008 \\
\hline & Non-squamous & $42(59.2 \%)$ & $65(79.3 \%)$ & \\
\hline \multirow[t]{3}{*}{ Anti-PD1/PD-L1 agent, n (\%) } & Nivolumab & $24(33.8 \%)$ & $48(58.5 \%)$ & \\
\hline & Pembrolizumab & $40(56.3 \%)$ & $23(28.1 \%)$ & 0.002 \\
\hline & Atezolizumab & $7(9.9 \%)$ & $11(13.4 \%)$ & \\
\hline \multirow[t]{3}{*}{ No. of prior lines, $\mathrm{n}(\%)$} & 0 & $19(26.8 \%)$ & $11(13.4 \%)$ & 0.101 \\
\hline & $1-2$ & $41(57.7 \%)$ & $53(64.6 \%)$ & \\
\hline & $\geq 3$ & $11(15.5 \%)$ & $18(22.0 \%)$ & \\
\hline \multirow[t]{2}{*}{ PD-L1 status, n (\%) } & $<50 \%$ & $24(33.8 \%)$ & $19(23.2 \%)$ & 0.836 \\
\hline & $\geq 50 \%$ & $30(42.3 \%)$ & $21(25.6 \%)$ & \\
\hline \multirow[t]{2}{*}{ Driver mutations, $\mathrm{n}(\%) \mathrm{a}$} & Positive & $0(0 \%)$ & $18(22.0 \%)$ & $<0.001$ \\
\hline & Negative & $66(93.0 \%)$ & $57(69.5 \%)$ & \\
\hline
\end{tabular}

ECOG PS: Eastern Cooperative Oncology Group Performance Status; PD-1: programmed cell death-1; PD-L1: programmed cell death-ligand 1. aEpidermal growth factor receptor mutations and anaplastic lymphoma kinase translocation. Statistically significant $p$-values are shown in bold.

Assessments and data collection. We investigated the presence of emphysema on CT scans with a 1-5 mm slice thickness. The CT images at the time of diagnosis were independently evaluated by two pulmonologists who were blinded to the clinical data. The kappa coefficient was used to assess the degree of interrater agreement on specific comparisons. Final decisions were agreed upon by consensus between the two pulmonologists. The presence of emphysema was scored using the Goddard scoring system (14). Briefly, emphysema was scored visually in the bilateral upper, middle, and lower lung fields. The score for each of the six dimensions was calculated according to the percentage of lowattenuation area in each lung field as follows: score $0,<5 \%$; score $1, \geq 5 \%-<25 \%$; score $2, \geq 25 \%-<50 \%$; score $3, \geq 50 \%-<75 \%$; and score $4, \geq 75 \%$. In the present study, we defined a total score of more than 8 points as the presence of emphysema. Demographic data, including age, sex, smoking history, and Eastern Cooperative Oncology Group (ECOG) performance status, were collected from electronic medical records.

Study design. PFS was measured from the date of starting ICIs to the date of initial disease progression, death from any cause, or the date last known to be alive without disease progression. Overall survival (OS) was measured from the date of starting ICIs to death from any cause or the date last known to be alive. The objective response rate and disease control rate were evaluated using the Response Evaluation Criteria for Solid Tumors, version 1.1 (15). Immune-related AEs (irAEs) were assessed according to the Common Terminology Criteria for Adverse Events, version 4.0 (16).
Table II. Response rates of patients with and without emphysema.

\begin{tabular}{lccc}
\hline Best response & \multicolumn{2}{c}{ Emphysema } & $p$-Value \\
& With (N=71) & Without (N=82) & \\
& $1(1.4 \%)$ & $0(0 \%)$ & $\mathbf{0 . 0 2 1}$ \\
Complete & $22(31.0 \%)$ & $13(15.9 \%)$ & \\
Partial & $25(35.2 \%)$ & $25(30.5 \%)$ & \\
Stable disease & $21(29.6 \%)$ & $40(48.8 \%)$ & \\
Progressive disease & $23(32.4 \%)$ & $13(15.9 \%)$ & $\mathbf{0 . 0 2 2}$ \\
Objective response rate & $48(67.6 \%)$ & $38(46.3 \%)$ & $\mathbf{0 . 0 1 2}$ \\
Disease control rate & & \\
\hline
\end{tabular}

Statistically significant $p$-values are shown in bold.

Statistical analysis. Data are presented as means \pm standard deviation or number (\%) of patients. Differences between groups were assessed by Student's $t$-test and Fisher's exact test. The Kaplan-Meier method was used to estimate PFS and OS rates, and the log-rank test was used to determine the differences in survival rates. Cox proportional hazards models were used for univariate and multivariate analyses to estimate hazard ratios (HRs) with $95 \%$ confidence intervals (CIs). All statistical analyses were performed using EZR software (Saitama Medical Center, Jichi Medical University, Saitama, Japan), a graphical user interface for R (The $\mathrm{R}$ Foundation for Statistical Computing, Vienna, Austria); EZR is a modified version of $\mathrm{R}$ commander designed to add frequently 

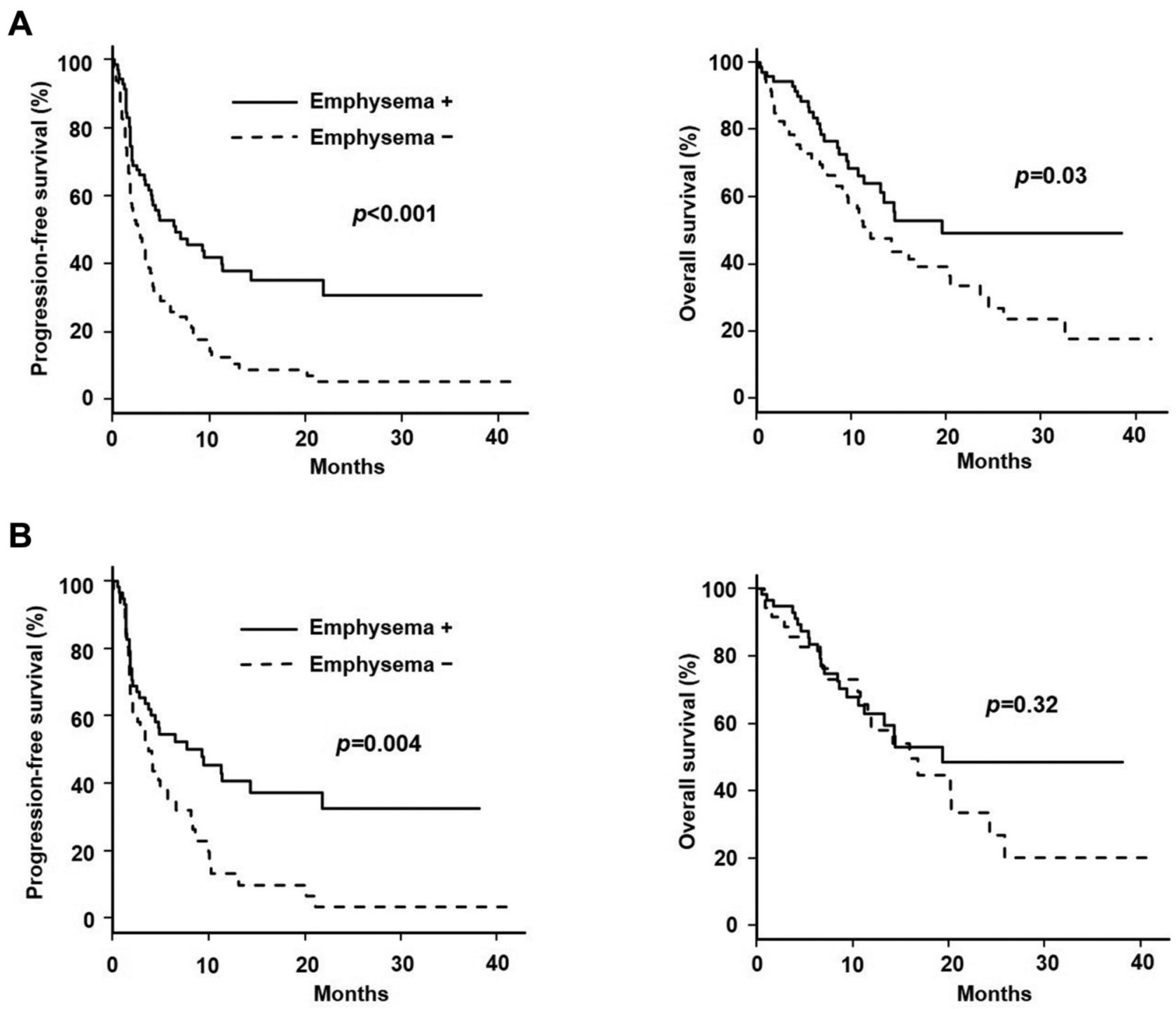

Figure 1. Kaplan-Meier curves of progression-free survival (PFS; left) and overall survival (OS; right) in patients with (+) and those without (-) emphysema in the overall cohort $(N=152)(A)$ and in patients with $\geq 30$ pack-years $(N=95)(B)$.

used statistical functions (17). $p$-Values of less than 0.05 were considered significant.

\section{Results}

Patient characteristics. Of 153 patients with advanced NSCLC, 72 underwent nivolumab monotherapy, 63 underwent pembrolizumab monotherapy, and 18 underwent atezolizumab monotherapy. This was the first exposure to ICIs for all patients. According to the Goddard scoring system, 71 (46.4\%) patients were classified as having emphysema and $82(53.6 \%)$ as having no emphysema (Table I). The kappa coefficient of diagnostic agreement was 0.81 . No significant difference in age, body mass index, ECOG performance status, or lines of treatment was observed between the two groups. Patients with emphysema had a male predominance and a greater number of tobacco smoking pack-years $(p<0.001)$ compared with patients without emphysema. In addition, they also had a higher prevalence of squamous-cell carcinoma. PD-L1 expression was evaluated in 94 patients, and there was no difference in the PDL1 tumor proportion score (TPS) between patients with and those without emphysema. Among the patients without emphysema, 17 were positive for mutation of epidermal growth factor receptor $(E G F R)$ gene, and one was positive for anaplastic lymphoma kinase $(A L K)$ gene translocation.

ICI treatment outcomes of NSCLC in patients with and those without emphysema. The objective response rate was 
Table III. Univariate and multivariate analyses for progression-free survival.

\begin{tabular}{|c|c|c|c|c|c|}
\hline \multirow[t]{2}{*}{ Characteristic } & & \multicolumn{2}{|c|}{ Univariate } & \multicolumn{2}{|c|}{ Multivariate } \\
\hline & & $\mathrm{HR}(95 \% \mathrm{Cl})$ & $p$-Value & $\mathrm{HR}(95 \% \mathrm{Cl})$ & $p$-Value \\
\hline Gender & Male versus female & $1.12(0.73-1.73)$ & 0.597 & $0.99(0.50-1.96)$ & 0.978 \\
\hline ECOG PS & $\geq 2$ versus $0-1$ & $3.28(1.85-5.84)$ & $<0.001$ & $2.36(1.04-5.40)$ & 0.041 \\
\hline Smoking pack-years & $\geq 30$ versus $<30$ & $0.58(0.40-0.86)$ & 0.007 & $0.65(0.37-1.13)$ & 0.123 \\
\hline Histological type & Squamous versus non-squamous & $0.81(0.54-1.22)$ & 0.307 & $0.92(0.50-1.70)$ & 0.796 \\
\hline No. of prior lines & $\geq 1$ versus 0 & $1.50(0.91-2.46)$ & 0.108 & $1.03(0.50-2.14)$ & 0.935 \\
\hline PD-L1 status & $\geq 50 \%$ versus $<50 \%$ & $0.68(0.42-1.12)$ & 0.132 & $0.70(0.41-1.18)$ & 0.180 \\
\hline Driver mutations & With versus without & $2.14(1.25-3.67)$ & 0.006 & $1.08(0.42-2.78)$ & 0.879 \\
\hline Emphysema & With versus without & $0.47(0.32-0.69)$ & $<0.001$ & $0.49(0.28-0.84)$ & 0.010 \\
\hline
\end{tabular}

HR: Hazard ratio; Cl: confidence interval; ECOG PS: Eastern Cooperative Oncology Group Performance Status; PD-L1: programmed cell deathligand 1. Statistically significant $p$-values are shown in bold.

Table IV. Univariate and multivariate analyses for overall survival.

\begin{tabular}{|c|c|c|c|c|c|}
\hline \multirow[t]{2}{*}{ Characteristic } & & \multicolumn{2}{|c|}{ Univariate } & \multicolumn{2}{|c|}{ Multivariate } \\
\hline & & $\mathrm{HR}(95 \% \mathrm{Cl})$ & $p$-Value & $\mathrm{HR}(95 \% \mathrm{Cl})$ & $p$-Value \\
\hline Age & $\geq 65$ versus $<65$ Years & $1.40(0.83-2.37)$ & 0.212 & $1.46(0.63-3.34)$ & 0.377 \\
\hline Gender & Male versus female & $1.09(0.63-1.88)$ & 0.749 & $1.23(0.53-2.88)$ & 0.626 \\
\hline ECOG PS & $\geq 2$ versus $0-1$ & $9.05(4.60-17.79)$ & $<0.001$ & $6.96(2.87-16.88)$ & $<0.001$ \\
\hline Smoking pack-years & $\geq 30$ versus $<30$ & $0.64(0.40-1.04)$ & 0.071 & $0.56(0.28-1.12)$ & 0.104 \\
\hline Histological type & Squamous versus non-squamous & $0.81(0.48-1.36)$ & 0.422 & $0.75(0.33-1.75)$ & 0.513 \\
\hline No. of prior lines & $\geq 1$ versus 0 & $1.18(0.63-2.19)$ & 0.607 & $1.21(0.55-2.68)$ & 0.641 \\
\hline PD-L1 status & $\geq 50 \%$ versus $<50 \%$ & $0.82(0.43-1.56)$ & 0.538 & $0.90(0.38-2.17)$ & 0.821 \\
\hline Driver mutations & With versus without & $0.96(0.46-2.01)$ & 0.914 & $0.34(0.10-1.23)$ & 0.010 \\
\hline Emphysema & With versus without & $0.58(0.36-0.94)$ & 0.026 & $0.57(0.27-1.20)$ & 0.138 \\
\hline
\end{tabular}

HR: Hazard ratio; Cl: confidence interval; ECOG PS: Eastern Cooperative Oncology Group Performance Status; PD-L1: programmed cell deathligand 1 .

significantly higher in patients with than in those without emphysema (32.4\% versus $15.9 \%$; $p=0.022)$, and the disease control rate was also higher in patients with emphysema (67.6\% vs. 46.3\%; $p=0.012$ ) (Table II). In addition, patients with emphysema had a better PFS (median 6.6 versus 2.7 months; $\mathrm{HR}=0.47,95 \% \mathrm{CI}=0.32-0.69 ; p<0.001)$ and $\mathrm{OS}$ (median 19.5 versus 11.6 months; $\mathrm{HR}=0.58$, 95\% CI=0.36$0.94 ; p=0.03)$ compared with patients without emphysema (Figure 1A). We next examined the impact of emphysema on PFS in the patients with a history of smoking. In the overall cohort, tobacco exposure of 30 pack-years or more was associated with a better PFS (median 4.9 versus 2.7 months, $\mathrm{HR}=0.58,95 \% \mathrm{CI}=0.40-0.86 ; p=0.006)$. Notably, patients with emphysema had a better PFS compared with those without, even among those with $\geq 30$ pack-years (median 9.3 versus 3.8 months, $\mathrm{HR}=0.49,95 \% \mathrm{CI}=0.30-0.80 ; p=0.004)$, although no significant difference in OS was observed (Figure 1B). Multivariate analyses showed that a good ECOG performance status and coexisting emphysema
$(\mathrm{HR}=0.49,95 \% \mathrm{CI}=0.28-0.84 ; p=0.010)$ were independent predictors of better PFS (Table III); however, coexisting emphysema did not remain a statistically significant predictor of OS in the multivariate analysis (Table IV).

Outcome of ICI treatment of patients with NSCLC according to coexisting emphysema and PD-L1 expression. We examined the prognostic significance of coexisting pulmonary emphysema according to PD-L1 expression. The PD-L1 expression status was evaluated in 94 patients. As expected, PFS tended to be longer in patients with PD-L1 TPS $\geq 50 \%$ compared with TPS $<50 \%$ (median 6.0 versus 3.4 months, HR=0.68, 95\% CI=0.42-1.12; $p=0.128$ ) (Figure 2A). Moreover, patients with both high PD-L1 expression and coexisting emphysema tended to have a longer PFS than that of patients with only one of these factors (Figure 2B).

Analysis of immune-related adverse events. The irAEs that developed are summarized in Table V. irAEs of any grade were 
A

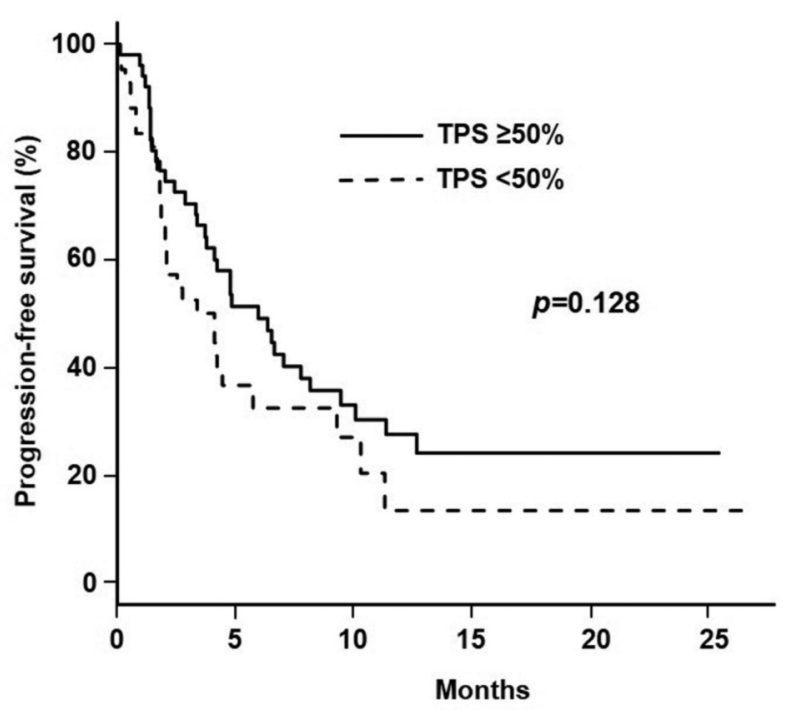

B

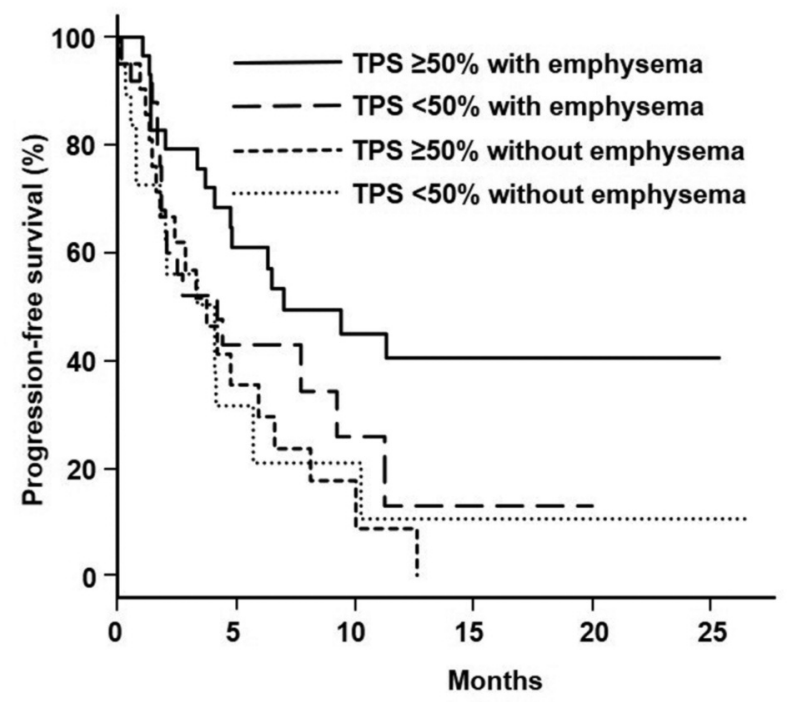

Figure 2. Kaplan-Meier curves of progression-free survival (PFS) according to the level of programmed cell death ligand 1 (PD-L1) expression $(N=94)(A)$ and PD-L1 expression with/without coexisting emphysema (B). The median PFS (95\% confidence intervaI) was 7.1 (4.1-not reached) months in patients with a PD-L1 tumor proportion score (TPS) $\geq 50 \%$ with emphysema (N=29), 4.2 (1.9-9.3) months in patients with a PD-L1 $T P S<50 \%$ with emphysema (N=25), 3.8 (1.6-6.6) months in patients with PD-L1 TPS $\geq 50 \%$ without emphysema (N=21), and 4.1 (0.8-5.8) months in patients with PD-L1 TPS $<50 \%$ without emphysema $(N=19)(B)$.

observed in 56 patients $(36.6 \%)$ and grade $3 / 4$ irAEs in 16 patients $(10.5 \%)$. However, no difference in the irAE rates was observed between patients with emphysema and those without.

\section{Discussion}

The present study showed that emphysema coexisting with NSCLC was associated with a longer PFS and OS and a higher objective response rate in patients treated with ICIs. In addition, the survival benefit of coexisting emphysema in patients with NSCLC treated with ICIs persisted even after adjustment for all relevant covariates. Moreover, no difference in the rates of irAEs was observed between patients with and those without emphysema.

To our knowledge, this is the first study to show an association between coexisting emphysema and an improved response to ICIs. We used a visual CT scoring system to assess the presence of emphysema. Previous studies have reported that visual CT scores are correlated with pathological findings (18) and respiratory functions $(14,19)$. Notably, the Goddard semiquantitative scoring system can be performed easily and quickly (14). Moreover, almost all patients with lung cancer undergo chest CT scans for diagnosis and staging during the initial evaluation. Thus, it may be clinically useful to identify emphysema using visual CT scores, such as the Goddard scoring system, in predicting the efficacy of ICIs in patients with NSCLC.
Table V. Immune-related adverse events (irAEs) in patients with and without emphysema.

\begin{tabular}{llccc}
\hline irAEs & & \multicolumn{2}{c}{ Emphysema, n (\%) } & \multirow{2}{*}{-Value } \\
\cline { 3 - 4 } & & With (N=71) & With (N=82) & \\
\hline \multirow{4}{*}{ Grade } & Total & $27(38.0 \%)$ & $29(35.4 \%)$ & 0.74 \\
& $1 / 2$ & $17(23.9 \%)$ & $23(28.0 \%)$ & 0.382 \\
& $3 / 4$ & $10(14.1 \%)$ & $6(7.3 \%)$ & \\
Type & Pneumonitis & $10(14.1 \%)$ & $7(8.5 \%)$ & 0.311 \\
& Skin reaction & $5(7.0 \%)$ & $9(11.0 \%)$ & 0.575 \\
& Hypothyroidism & $4(5.6 \%)$ & $9(11.0 \%)$ & 0.263 \\
& Hypophysitis & $4(5.6 \%)$ & $2(2.4 \%)$ & 0.417 \\
& Colitis & $3(4.2 \%)$ & $1(1.2 \%)$ & 0.338 \\
\hline
\end{tabular}

The mechanism underlying the better outcome of emphysematous NSCLC patients treated with ICIs remains unclear. However, a few mechanisms underlying an improved outcome in patients with COPD treated with ICIs have been proposed. Firstly, CD4 ${ }^{+}$T-cell differentiation is skewed toward the interferon- $\gamma$-producing T-helper type 1 phenotype in the setting of COPD (20). Th1 immunity in a subset of patients with COPD may be responsible for a better ICI treatment outcome because the existence of an interferon- $\gamma$-related gene signature was recently shown to predict a favorable anti-PD1 treatment response (21). 
Secondly, it was reported that patients with NSCLC with COPD displayed tumor-infiltrating T-lymphocyte exhaustion, identified by enhanced immunostaining of PD1 and T-cell immunoglobulin mucin 3 in $\mathrm{CD}^{+}$cells $(12,20)$. Thus, immune activity was suggested to be enhanced in patients with NSCLC with COPD. We speculate that high ICI efficacy in NSCLC is obtained in patients with emphysema by the same mechanism as in patients with COPD.

Current or former smokers with NSCLC are more likely to respond to ICI therapy $(2,3)$, and similar results were found in the present study. Notably, PFS was better in patients with emphysema than in those without even among the patients with a smoking history of 30 or more packyears. In addition, multivariate analysis showed that emphysema had a stronger association with PFS than did smoking status. A previous study reported that COPD and tobacco smoking have a synergistic impact on $\mathrm{CD}^{+}$tumorinfiltrating T-lymphocyte exhaustion and on the prognostic value of immune cells (12), supporting our results.

It has been reported that patients with high PD-L1 expression in tumor cells are more likely to respond to treatment with ICIs $(2,3)$, and similar results were found in the present study. The relationship between PD-L1 expression and emphysema remains unclear, even though some studies $(22,23)$ have evaluated this. In the present study, there was no difference in PD-L1 expression between patients with and those without emphysema. Therefore, we speculate that the PD-L1 expression status and emphysema are independent prognostic factors for PFS in patients with NSCLC treated with ICIs. In our study, patients with both high PD-L1 expression and emphysema tended to have a longer PFS compared with patients with only one of these factors. Treatment with ICIs may have a favorable antitumor effect in these patients.

In the present study, no difference in the rate of irAEs was observed between patients with emphysema and those without. Previous studies indicated that the presence of emphysema is not associated with the occurrence of ICI-induced interstitial lung disease $(24,25)$. Thus, the presence of emphysema is likely not a factor hindering treatment with ICIs.

The present study has several limitations. Firstly, this was a retrospective, single-center study with a small sample size. Secondly, ICIs have shown minimal therapeutic benefit in patients with $E G F R$ mutations $(2,4,26)$. In the present study, a higher proportion of the patients without emphysema had EGFR mutations. However, the driver mutation status, such as EGFR gene mutations and $A L K$ gene translocation, was not associated with PFS in the multivariate analysis. Thirdly, we used the Goddard scoring system to assess the existence of emphysema. Although this method is simple and can be performed quickly, visual inspection is thought to be affected by interobserver and intraobserver variabilities. Therefore, additional detailed examinations using quantitative standardized assessments with computer algorithms are required to assess the existence of emphysema.

\section{Conclusion}

In this study, emphysema coexisting with NSCLC was associated with longer PFS and OS and a higher response rate to ICI treatment. In addition, emphysema had a stronger association with PFS than did smoking status. Therefore, recognizing coexisting emphysema may help predict the therapeutic efficacy of ICIs in patients with NSCLC.

\section{Conflict of Interest}

The Authors declare no conflicts of interest associated with this study.

\section{Authors' Contributions}

Y.T and H.S. devised the project and main conceptual ideas. Y.T and T.N. performed the retrospective chart review, carried out radiological measurements, and conducted the statistical analysis. Y.F, S.M, and K.M. supervised the project. All Authors gave final approval for publication.

\section{References}

1 Torre LA, Bray F, Siegel RL, Ferlay J, Lortet-Tieulent J and Jemal A: Global cancer statistics. CA Cancer J Clin 65(2): 87108, 2015. PMID: 25651787. DOI: 10.3322/caac.21262

2 Borghaei H, Paz-Ares L, Horn L, Spigel DR, Steins M, Ready NE, Chow LQ, Vokes EE, Felip E, Holgado E, Barlesi F, Kohlhäufl M, Arrieta O, Burgio MA, Fayette J, Lena H, Poddubskaya E, Gerber DE, Gettinger SN, Rudin CM, Rizvi N, Crinò L, Blumenschein GR Jr, Antonia SJ, Dorange C, Harbison $\mathrm{CT}$, Graf Finckenstein $\mathrm{F}$ and Brahmer JR: Nivolumab versus docetaxel in advanced nonsquamous non-small-cell lung cancer. N Engl J Med 373(17): 1627-39, 2015. PMID: 26412456. DOI: 10.1056/NEJMoa1507643

3 Reck M, Rodríguez-Abreu D, Robinson AG, Hui R, Csőszi T, Fülöp A, Gottfried M, Peled N, Tafreshi A, Cuffe S, O'Brien M, Rao S, Hotta K, Leiby MA, Lubiniecki GM, Shentu Y, Rangwala $\mathrm{R}$ and Brahmer JR: Pembrolizumab versus chemotherapy for PD-L1-positive non-small-cell lung cancer. N Engl J Med 375(19): 1823-1833, 2016. PMID: 27718847. DOI: 10.1056/NEJMoa1606774

4 Rittmeyer A, Barlesi F, Waterkamp D, Park K, Ciardiello F, von Pawel J, Gadgeel SM, Hida T, Kowalski DM, Dols MC, Cortinovis DL, Leach J, Polikoff J, Barrios C, Kabbinavar F, Frontera OA, De Marinis F, Turna H, Lee JS, Ballinger M, Kowanetz M, He P, Chen DS, Sandler A and Gandara DR: Atezolizumab versus docetaxel in patients with previously treated non-small-cell lung cancer (OAK): A phase 3, open-label, multicentre randomized controlled trial. Lancet 389(10066): 255-265, 2017. PMID: 27979383. DOI: 10.1016/S0140-6736(16)32517-X

5 Patel SP and Kurzrock R: PD-L1 expression as a predictive biomarker in cancer immunotherapy. Mol Cancer Ther 14(4): 847-856, 2015. PMID: 25695955. DOI: 10.1158/15357163.MCT-14-0983 
6 Rizvi NA, Hellmann MD, Snyder A, Kvistborg P, Makarov V, Havel JJ, Lee W, Yuan J, Wong P, Ho TS, Miller ML, Rekhtman N, Moreira AL, Ibrahim F, Bruggeman C, Gasmi B, Zappasodi R, Maeda Y, Sander C, Garon EB, Merghoub T, Wolchok JD, Schumacher TN and Chan TA: Mutational landscape determines sensitivity to PD-1 blockade in non-small cell lung cancer. Science 348(6230): 124-128, 2015. PMID: 25765070. DOI: 10.1126/science.aaa 1348

7 Prat A, Navarro A, Paré L, Reguart N, Galván P, Pascual T, Martínez A, Nuciforo P, Comerma L, Alos L, Pardo N, Cedrés S, Fan C, Parker JS, Gaba L, Victoria I, Viñolas N, Vivancos A, Arance A and Felip E: Immune-related gene expression profiling after PD-1 blockade in non-small cell lung carcinoma, head and neck squamous cell carcinoma, and melanoma. Cancer Res 77(13): 3540-3550, 2017. PMID: 28487385. DOI: 10.1158/ 0008-5472.CAN-16-3556

8 Lim SS, Vos T, Flaxman AD, Danaei G, Shibuya K, AdairRohani H, Amann M, Anderson HR, Andrews KG, Aryee M, Atkinson C, Bacchus LJ, Bahalim AN, Balakrishnan K, Balmes J, Barker-Collo S, Baxter A, Bell ML, Blore JD, Blyth F, Bonner C, Borges G, Bourne R, Boussinesq M, Brauer M, Brooks P, Bruce NG, Brunekreef B, Bryan-Hancock C, Bucello C, Buchbinder R, Bull F, Burnett RT, Byers TE, Calabria B, Carapetis J, Carnahan E, Chafe Z, Charlson F, Chen H, Chen JS, Cheng AT, Child JC, Cohen A, Colson KE, Cowie BC, Darby S, Darling S, Davis A, Degenhardt L, Dentener F, Des Jarlais DC, Devries K, Dherani M, Ding EL, Dorsey ER, Driscoll T, Edmond K, Ali SE, Engell RE, Erwin PJ, Fahimi S, Falder G, Farzadfar F, Ferrari A, Finucane MM, Flaxman S, Fowkes FG, Freedman G, Freeman MK, Gakidou E, Ghosh S, Giovannucci E, Gmel G, Graham K, Grainger R, Grant B, Gunnell D, Gutierrez HR, Hall W, Hoek HW, Hogan A, Hosgood HD 3rd, Hoy D, Hu H, Hubbell BJ, Hutchings SJ, Ibeanusi SE, Jacklyn GL, Jasrasaria R, Jonas JB, Kan H, Kanis JA, Kassebaum N, Kawakami N, Khang YH, Khatibzadeh S, Khoo JP, Kok C, Laden F, Lalloo R, Lan Q, Lathlean T, Leasher JL, Leigh J, Li Y, Lin JK, Lipshultz SE, London S, Lozano R, Lu Y, Mak J, Malekzadeh R, Mallinger L, Marcenes W, March L, Marks R, Martin R, McGale P, McGrath J, Mehta S, Mensah GA, Merriman TR, Micha R, Michaud C, Mishra V, Mohd Hanafiah K, Mokdad AA, Morawska L, Mozaffarian D, Murphy T, Naghavi M, Neal B, Nelson PK, Nolla JM, Norman R, Olives C, Omer SB, Orchard J, Osborne R, Ostro B, Page A, Pandey KD, Parry CD, Passmore E, Patra J, Pearce N, Pelizzari PM, Petzold M, Phillips MR, Pope D, Pope CA 3rd, Powles J, Rao M, Razavi H, Rehfuess EA, Rehm JT, Ritz B, Rivara FP, Roberts T, Robinson C, Rodriguez-Portales JA, Romieu I, Room R, Rosenfeld LC, Roy A, Rushton L, Salomon JA, Sampson U, Sanchez-Riera L, Sanman E, Sapkota A, Seedat S, Shi P, Shield K, Shivakoti R, Singh GM, Sleet DA, Smith E, Smith KR, Stapelberg NJ, Steenland K, Stöckl H, Stovner LJ, Straif K, Straney L, Thurston GD, Tran JH, Van Dingenen R, van Donkelaar A, Veerman JL, Vijayakumar L, Weintraub R, Weissman MM, White RA, Whiteford H, Wiersma ST, Wilkinson JD, Williams HC, Williams W, Wilson N, Woolf AD, Yip P, Zielinski JM, Lopez AD, Murray CJ, Ezzati M, AlMazroa MA and Memish ZA: A comparative risk assessment of burden of disease and injury attributable to 67 risk factors and risk factor clusters in 21 regions, 1990-2010: A systematic analysis for the Global Burden of Disease Study. Lancet 380(9859):
2224-2260, 2012. PMID: 23245609. DOI: 10.1016/S01406736(12)61766-8

9 de Torres JP, Marín JM, Casanova C, Cote C, Carrizo S, Cordoba-Lanus E, Baz-Dávila R, Zulueta JJ, Aguirre-Jaime A, Saetta M, Cosio MG and Celli BR: Lung cancer in patients with chronic obstructive pulmonary disease- incidence and predicting factors. Am J Respir Crit Care Med 184(8): 913-919, 2011. PMID: 21799072. DOI: 10.1164/rccm.201103-0430OC

10 Gao YH, Guan WJ, Liu Q, Wang HQ, Zhu YN, Chen RC and Zhang GJ: Impact of COPD and emphysema on survival of patients with lung cancer: A meta-analysis of observational studies. Respirology 21(2): 269-279, 2016. PMID: 26567533. DOI: $10.1111 /$ resp.12661

11 Mark NM, Kargl J, Busch SE, Yang GHY, Metz HE, Zhang H, Hubbard JJ, Pipavath SNJ, Madtes DK and Houghton AM: Chronic obstructive pulmonary disease alters immune cell composition and immune checkpoint inhibitor efficacy in nonsmall cell lung cancer. Am J Respir Crit Care Med 197(3): 325336, 2018. PMID: 28934595. DOI: $10.1164 / \mathrm{rccm} .201704-$ $07950 \mathrm{C}$

12 Biton J, Ouakrim H, Dechartres A, Alifano M, Mansuet-Lupo A, Si H, Halpin R, Creasy T, Bantsimba-Malanda C, Arrondeau J, Goldwasser F, Boudou-Rouquette P, Fournel L, Roche N, Burgel PR, Goc J, Devi-Marulkar P, Germain C, Dieu-Nosjean MC, Cremer I, Herbst R and Damotte D: Impaired tumor-infiltrating $\mathrm{T}$-cells in patients with chronic obstructive pulmonary disease impact lung cancer response to PD-1 blockade. Am J Respir Crit Care Med 198(7): 928-940, 2018. PMID: 29518341. DOI: 10.1164/rccm.201706-1110OC

13 Shin SH, Park HY, Im Y, Jung HA, Sun JM, Ahn JS, Ahn MJ, Park K, Lee HY and Lee SH: Improved treatment outcome of pembrolizumab in patients with non-small cell lung cancer and chronic obstructive pulmonary disease. Int J Cancer 145(9): 2433-2439, 2019. PMID: 30807641. DOI: 10.1002/ijc.32235

14 Goddard PR, Nicholson EM, Laszlo G and Watt I: Computed tomography in pulmonary emphysema. Clin Radiol 33(4): 379-87, 1982. PMID: 7083738. DOI: 10.1016/s0009-9260(82)80301-2

15 Eisenhauer EA, Therasse P, Bogaerts J, Schwartz LH, Sargent D, Ford R, Dancey J, Arbuck S, Gwyther S, Mooney M, Rubinstein L, Shankar L, Dodd L, Kaplan R, Lacombe D and Verweij J: New response evaluation criteria in solid tumours: Revised RECIST guideline (version 1.1). Eur J Cancer 45(2): 228-247, 2009. PMID: 19097774. DOI: 10.1016/j.ejca. 2008.10.026

16 Chen AP, Setser A, Anadkat MJ, Cotliar J, Olsen EA, Garden BC and Lacouture ME: Grading dermatologic adverse events of cancer treatments: the Common Terminology Criteria for Adverse Events Version 4.0. J Am Acad Dermatol 67(5): 10251039, 2012. PMID: 22502948. DOI: 10.1016/j.jaad.2012.02.010

17 Kanda Y: Investigation of the freely available easy-to-use software 'EZR' for medical statistics. Bone Marrow Transplant 48(3): 452-458, 2013. PMID: 23208313. DOI: 10.1038/bmt. 2012.244

18 Müller NL, Staples CA, Miller RR and Abboud RT: "Density mask". An objective method to quantitate emphysema using computed tomography. Chest 94(4): 782-787, 1988. PMID: 3168574. DOI: $10.1378 /$ chest.94.4.782

19 Park KJ, Bergin CJ and Clausen JL: Quantitation of emphysema with three-dimensional CT densitometry: Comparison with twodimensional analysis, visual emphysema scores, and pulmonary 
function test results. Radiology 211(2): 541-547, 1999. PMID: 10228540. DOI: 10.1148/radiology.211.2.r99ma52541

20 Houghton AM: Common mechanisms linking chronic obstructive pulmonary disease and lung cancer. Ann Am Thorac Soc 15(Suppl 4): S273-S277, 2018. PMID: 30759018. DOI: 10.1513/AnnalsATS.201808-537MG

21 Ayers M, Lunceford J, Nebozhyn M, Murphy E, Loboda A, Kaufman DR, Albright A, Cheng JD, Kang SP, Shankaran V, Piha-Paul SA, Yearley J, Seiwert TY, Ribas A and McClanahan TK: IFN- $\gamma$-related mRNA profile predicts clinical response to PD-1 blockade. J Clin Invest 127(8): 2930-2940, 2017. PMID: 28650338. DOI: 10.1172/JCI91190

22 Toyokawa G, Takada K, Okamoto T, Kozuma Y, Matsubara T, Haratake N, Takamori S, Akamine T, Katsura M, Shoji F, Oda $\mathrm{Y}$ and Maehara Y: High frequency of programmed death-ligand 1 expression in emphysematous bullae-associated lung adenocarcinomas. Clin Lung Cancer 18(5): 504-511.e1, 2017. PMID: 28038981. DOI: 10.1016/j.cllc.2016.11.011

23 Arimura K, Sekine Y, Hiroshima K, Shimizu S, Shibata N, Kondo M, Takeyama K and Tagaya E: PD-L1, FGFR1, PIK3CA, PTEN, and p16 expression in pulmonary emphysema and chronic obstructive pulmonary disease with resected lung squamous cell carcinoma. BMC Pulm Med 19(1): 169, 2019. PMID: 31481045. DOI: 10.1186/s12890-019-0913-8
24 Yamaguchi T, Shimizu J, Hasegawa T, Horio Y, Inaba Y, Yatabe $\mathrm{Y}$ and Hida T: Pre-existing pulmonary fibrosis is a risk factor for anti-PD-1-related pneumonitis in patients with non-small cell lung cancer: A retrospective analysis. Lung Cancer 125: 212217, 2018. PMID: 30429022. DOI: 10.1016/j.lungcan

25 Nakanishi Y, Masuda T, Yamaguchi K, Sakamoto S, Horimasu Y, Nakashima T, Miyamoto S, Tsutani Y, Iwamoto H, Fujitaka K, Miyata Y, Hamada H, Okada M and Hattori N: Pre-existing interstitial lung abnormalities are risk factors for immune checkpoint inhibitor-induced interstitial lung disease in nonsmall cell lung cancer. Respir Investig 57(5): 451-459, 2019. PMID: 31248832. DOI: 10.1016/j.resinv.2019.05.002

26 Herbst RS, Baas P, Kim DW, Felip E, Pérez-Gracia JL, Han JY, Molina J, Kim JH, Arvis CD, Ahn MJ, Majem M, Fidler MJ, de Castro G Jr, Garrido M, Lubiniecki GM, Shentu Y, Im E, Dolled-Filhart $\mathrm{M}$ and Garon EB: Pembrolizumab versus docetaxel for previously treated, PD-L1-positive, advanced nonsmall-cell lung cancer (KEYNOTE-010): A randomized controlled trial. Lancet 387(10027): 1540-1550, 2016. PMID: 26712084. DOI: 10.1016/S0140-6736(15)01281-7

Received September 30, 2020

Revised October 13, 2020

Accepted October 14, 2020 